August 2009

\title{
The Genocide Prevention Task Force: Recycling People and Policy
}

Herb Hirsch

Follow this and additional works at: https://digitalcommons.usf.edu/gsp

\section{Recommended Citation}

Hirsch, Herb (2009) "The Genocide Prevention Task Force: Recycling People and Policy," Genocide Studies and Prevention: An International Journal: Vol. 4: Iss. 2: Article 4.

Available at: https://digitalcommons.usf.edu/gsp/vol4/iss2/4

This Articles is brought to you for free and open access by the Open Access Journals at Digital Commons @ University of South Florida. It has been accepted for inclusion in Genocide Studies and Prevention: An International Journal by an authorized editor of Digital Commons @ University of South Florida. For more information, please contact digitalcommons@usf.edu. 


\title{
The Genocide Prevention Task Force: Recycling People and Policy
}

\author{
Herb Hirsch \\ Virginia Commonwealth University
}

For many who have spent most of their academic careers studying genocide, Preventing Genocide: A Blueprint for U.S. Policymakers (the Albright-Cohen Report) will be seen as a huge disappointment. ${ }^{1}$ Yes, perhaps it draws some minimal attention to the issue of genocide, but it is so hampered by its numerous flaws, and it appears at such an inopportune moment-with attention focused on what are, for the moment, more pressing issues-that it will likely have little, if any, impact.

There are certain obvious problems that may be illuminated by comparing the report to Gareth Evans' recent book The Responsibility to Protect. ${ }^{2}$ In fact, comparing the two illustrates clearly the weakness of the Albright-Cohen report and provides some indication of how our discussion here will proceed.

First, where Evans is clear, concise, and direct, this report is poorly written and filled with jargon that would drive a sane person crazy. Bureaucrat-speak is everywhere. Allow me to give you just one example, from page 88: "The United States could utilize templates of various political-military 'flexible deterrent options' as a matrix for genocide prevention." There follows, by the way, the suggestion that the United States should use "both kinetic and non-kinetic tasks."

Second, where Evans is forthright and accurate in his discussion of previous atrocity crimes and the response to them, or lack thereof, the Albright-Cohen Report at best fudges and at worst is revisionist. This is particularly true with respect to events in the former Yugoslavia and in Rwanda: the report appears to want to rewrite the sad history of those events and avoid forthright confrontation with the abysmal US response. Evans does not equivocate. In addition, the report virtually ignores the long historical record of genocide and the feeble response from the United States and elevates the eventual attempted response in Kosovo to a story of success not completely substantiated by events. Given such a weak analysis of history, the report cannot form the foundation of an adequate policy.

In addition, it is comical, perhaps ironic, how often proclamations of this type appear on the anniversary of an important past event-one supposes that this is intended to add gravitas and impact. In reality, of course, this is a convenient fiction allowing the report-and it is usually a report, rather than actual policy-to be released, announced, or celebrated on the anniversary of some past momentous event. In the case of the Genocide Prevention Task Force, the significant date was the sixtieth anniversary of the Convention on the Prevention and Punishment of the Crime of Genocide. Astute observers might ask why the task of preventing genocide was not discussed ten years ago (in 1998), when some of the authors were actually still in positions of power and had recently experienced the atrocities in the former Yugoslavia (1992-1995) and in Rwanda (1994)—which, if memory serves, they did very little to prevent or to stop. Or why not twenty years ago, before those sad events occurred, 
when perhaps the report's authors could have helped to prevent them. It is not as though genocide were unknown.

If one were cynical or suspicious, one might suspect an attempt to cleanse the record, to rewrite an unfortunate history by focusing on how to prevent a phenomenon that, in reality, is less common now than was at in the second half of the twentieth century (although surely those being slaughtered in Darfur would disagree, as would those experiencing the events in the DRC-if these are in fact instances of genocide). It is almost too convenient.

Third, and relatedly, the recycling business is alive and thriving in Washington, DC. In fact, as many have argued, there is a permanent Washington presence that recycles itself and then recycles policies. Past errors are conveniently forgotten or, at the very least, not admitted. The old adage that once one gets close to power one loses one's ability to criticize or to see alternatives is all the more obviously true if one observes both foreign and domestic policy making-notably the line of tragic US decisions from Vietnam and Cambodia through Bosnia and Rwanda to Darfur. Policy makers fool themselves into believing that they know more and better than anyone else what policies to pursue, and they are reluctant to break the cycles of past failures.

Fourth, to preserve this culture, the bureaucratic or government solution is to commission and issue reports. The endless number of such reports, resulting in fruitless policy or in no active policy at all, serves to remind us that this is what is known as co-optation: reports replace behavior. We are now led to believe, since the report has been written and submitted, that policy will follow. I could recite the long history of such reports, but lack of time prevents me from boring you further.

Fifth, Evans notes the decline of genocide and hostilities in the modern era, and it is most likely the case that the world presently faces what are perceived as more pressing problems: climate change and the global economic crisis have diverted the attention of most governments, and, after all, perhaps they are correct. Is genocide the most pressing problem facing us at present?

In conclusion, then, we must remember that the Albright-Cohen Report provides ample evidence of two clashing cultures. Academics often feel inadequate in the presence of policy makers, although we are quick to inform them of their inadequacies, while policy makers are just as quick to note that academics are naïve and do not have at their command the "realities" that they, the policy makers, face. This is most unfortunate and untrue.

Of course, I am aware of the response: "Don't judge us for our past failures, but focus on our present good intentions." Unfortunately, from Raphael Lemkin to the present-as these commentaries demonstrate, and numerous others who have studied genocide over the years, will note-good intentions do not prevent atrocity, and they very often are never translated into action. So we judge policy makers, past and present, on action, not on whether they have experience or good intentions.

With these broad criticisms in mind, we now move on to the more specific analysis of our commentators.

\section{Notes}

1. Madeleine K. Albright and William S. Cohen, chairs, Preventing Genocide: A Blueprint for U.S. Policymakers (Washington, DC: Genocide Prevention Task Force, 2008), http://www.usip.org/genocide_taskforce/report.html (accessed 10 June 2009).

2. Gareth Evans, The Responsibility to Protect: Ending Mass Atrocity Crimes Once and for All (Washington, DC: Brookings Institution Press, 2008). 